\title{
Attraction and Word of Mouth in a Visit Decision
}

\author{
Tri Palupi Robustin \\ Department of Management, STIE Widya Gama Lumajang \\ Email: tripalupirobustin@gmail.com
}

\section{A R T ICLE INFO}

Date of entry:

23 April 2020

Revision Date:

9 May 2020

Date Received:

12 May 2020

\begin{abstract}
A B S T R A C T
The purpose of this study was to determine the partial and simultaneous influence between attractiveness and word of mouth on the decision to visit Watu Ulo Beach in Jember Regency. The purpose of this study is explanatory (explanatory research) and predictions where explanatory research is a type of research that explains the causal relationship between one variable with other variables through hypothesis testing. The research population is tourists visiting Watu Ulo Beach. The sampling technique used is purposive sampling. The analysis used in this study is a multivariate analysis, namely, multiple linear regression analysis consisting entirely of 3 (three) variables. The number of samples in this study was 60 sample members. The results of this study indicate that the attractiveness and word of mouth influence partially and simultaneously on the decision to visit Watu Ulo Beach. The results of the multiple determination coefficient (R2) of 0.558 , this means that $55.8 \%$ of the visiting decision changes are influenced by the attractiveness and word of mouth variables while the remaining $44.2 \%$ is caused by other factors of promotion, service quality, an image of tourist attraction, and others not included in the regression equation created.
\end{abstract}

Keywords: Attraction, Word Of Mouth, Watu Ulo.
Cite this as: Robustin, T. P. (2020). Attraction and Word of Mouth in a Visit Decision. Jurnal Ilmu Manajemen Advantage. 4(1), 24-31. https://doi.org/10.30741/adv.v4i1.604

\section{INTRODUCTION}

Indonesia's tourism sector contributes to approximately $4 \%$ of the total economy. In 2019 , the Government of Indonesia wanted to double this figure to $8 \%$ of GDP, an ambitious (maybe too ambitious) target, which implies that in the next four years, the number of visitors needs to double to around 20 million. In order to achieve this target, the government will focus on improving Indonesia's infrastructure (including information and communication technology infrastructure), access, health \& hygiene, and also increasing online promotion campaigns (marketing) abroad (https://www.indonesia-investments.com/id/bisnis/industri-sektor/pariwisata/item6051). Indonesia is a country that is rich in resources, both natural and human resources. Besides being rich in resources, this country also has a lot of potential in several fields that can be developed as income (foreign exchange) for the country. One of them is the potential in the field of tourism because 
Indonesia is an archipelagic country, so it is not surprising that each region has diverse tourism potential.

Modeling these factors allows marketers to understand tourism behavior and the causality of their interactions better, taking into account personal tourist characteristics (socio-demographic and motivation) that have the potential to create satisfaction and loyalty. Medlik and Middleton (1973) note that tourism products are considered a mixture of three main components, namely the attractiveness of the place, the facilities at the destination, and the accessibility of the destination. Middleton and Clarke (2001) show that there are five main components in tourism products as a whole, and they are: attraction of the place and environment, place facilities and services, place accessibility, place description, and price. Quality services play an important role in tourism by increasing the level of tourist satisfaction (Al-Ababneh, 2013).

Today, where customers are flooded with thousands of advertising, promotional, and personal messages, the flow of WOM from people they trust is very important. Promotions that come out of the mouths of satisfied customers for your brand can significantly boost brand reputation. It also affects how products and services can be purchased, customer perceptions can be formed, and new trends that can be formed. WOM promotion from other people who are trusted by a customer can be a "blessing" for marketers. Almost every organization knows the true value and impact that can result from promotions from other parties that are trusted by customers.

The decision to visit the tourism context is adapted from the concept of consumer purchasing decisions. The five-stage purchasing decision model explains that consumers must go through five stages in the process of purchasing a product. However, this does not apply, especially for purchases with low involvement. Consumers can skip or reverse several stages; for example, in the context of tourism, tourists who have visited a destination (repeat visitors) from the need to travel to purchase decisions and skip the search for information evaluation.

Jember is one of the districts in East Java that has a fairly popular natural tourism object, namely its beaches. Jember's location in the southern part of the province of East Java is what makes most of the southern sea of Java into the Jember region. One of the southern beaches in Jember, which is quite popular, is Watu Ulo Beach. Watu Ulo is taken from the Javanese language 'Watu,' which means Stone and 'Ulo,' which is Snake. Overall, Watu Ulo is interpreted as Batu Ular. The naming is indeed in accordance with the condition of the beach, where there is a rock with a scaly structure on the edge of the beach that extends into the sea like a Snake Statue. The stone seemed to be a footbridge leading the visitors to the beach. The exact location of Watu Ulo Beach is in the village of Sumberejo, Ambulu sub-district, Jember district of East Java. To reach the location of the beach is actually quite easy because Watu Ulo Beach is in line with other popular beaches in Jember, so access to the location is quite easy. The most recommended route because visitors also usually use the route (https://www.pantainesia.com/pantai-watu-ulo). Cultural influences change according to changing times, just as outdated cultural patterns are replaced with new cultural patterns. Marketing executives must always be on the lookout for changes in these cultural patterns so they can adjust their marketing plans in tune with time or be a little more advanced than usual. According to Sangadji and Sopiah (2013: 87), some changes can affect marketing, one of which is an increase in leisure time. Family life now has more free time because they have shorter work hours per week, longer leave periods, and an increasing number of various automatic equipment used in the home. Changing lifestyles have resulted in the growth of markets in the field of sports equipment, recreational activities (traveling), physical fitness programs, and all types of products, as well as the equipment needed to engage in these activities. Based on the background and explanation, this study has a purpose, namely: a. To find out the influence of attractiveness on the decision to visit Watu Ulo Beach in Jember Regency; b. To find out the effect of word of mouth on the decision to visit Watu Ulo Beach in Jember Regency; c. To find out the simultaneous influence of attractiveness and word of mouth on the decision to visit Watu Ulo Beach in Jember Regency. 


\section{METHODS}

This research belongs to the type of survey research (survey research) that is research that does not make changes, or there is no special treatment of the variables studied (non-experimental). The purpose of this research is explanatory and explanatory research, where explanatory research is a type of research that explains the causal relationship between one variable and another through hypothesis testing. By its nature, this research is explorative because further testing of a study is needed. The research is exploratory.

This research was conducted on tourists visiting Watu Ulo Beach in Jember Regency. The reason the researchers chose the object of research on Watu Ulo Beach is that on this beach, there is a scaly rock with a structure on the edge of the beach that extends into the sea like a Snake Statue. The stone seems to be a bridge to guide visitors to the beach, and it is an attraction for Watu Ulo Beach. The other reason is that some changes that can affect marketing, one of which is to increase leisure time. Family life now has more free time because they have shorter work hours per week, longer leave periods, and an increasing number of various automatic equipment used in the home. Lifestyle has changed, resulting in the growth of the market, one of which is tourism services, so that travel has become a tourist need.

The data in this study, according to the source, is external data that is data obtained from tourists, while the type of data is primarily because the data is collected directly from the source, namely tourists visiting Watu Ulo Beach. This primary data is in the form of a questionnaire to capture the opinion of tourists related to attractiveness and word of mouth about Watu Ulo Beach.

Data collection techniques are using questionnaires or questionnaires given to respondents, both directly and with the help of the program manager. For distributing questionnaires as research material given to tourists visiting or traveling on Watu Ulo Beach, the aim is to solicit respondents' opinions about the appeal given by Watu Ulo Beach and word of mouth as well as their influence on tourist visiting decisions. Likert scale is designed to examine how strongly the subject agrees or disagrees with the statements submitted (Now, 2006: 31). The answer to each item that uses a Likert scale has a gradation from very positive to very negative. The range of scales used to measure the degree of strongly disagree or strongly agree for each indicator variable in this study is 1 (one) to 5 (five), with the weighting rate as follows: a. Strongly Agree: score 5, b. Agree: score 4, c. Neutral: score 3, d. Disagree: score 2, e. Strongly Disagree: score 1.

The population in this study was the public and visitors to B29 nature tourism in Lumajang. The sampling technique used in this study is simple random sampling, where the principle of sample selection is that every element in the population has the same opportunity to be chosen. The method of determining the sample size used is the method developed by Roscoe in his book Research Methods For Business (1982: 253) as quoted in (Sugiyono, 2009: 129) that is, if the research will conduct multivariate analysis, then the number of sample members is at least 10 ( ten) times the number of variables studied, including the number of independent and dependent variables. The analysis used in this study is a multivariate analysis that is multiple linear regression analysis consisting entirely of 3 (three) variables so that the sample size is taken at least $=20 \times 3$ variables $=60$ sample members. 


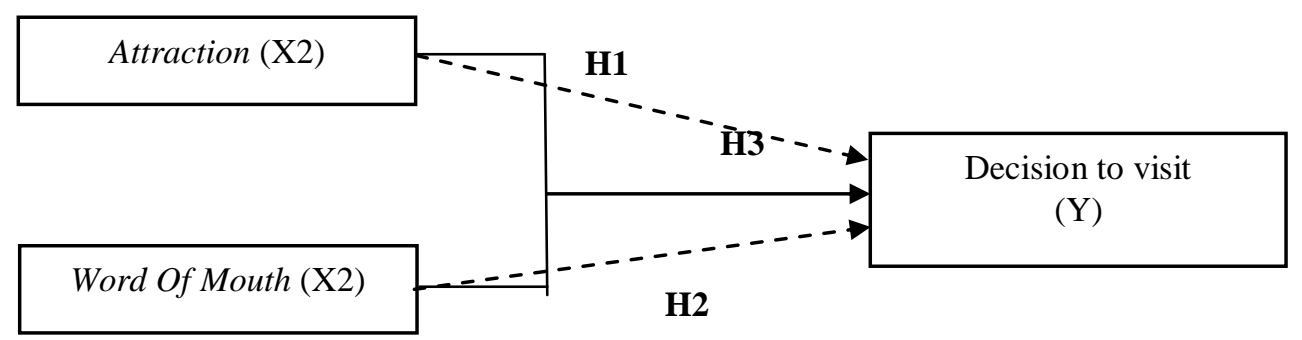

Figure 1. Research Model

Data source: Data processed in 2020

This study uses multiple linear regression analysis techniques. According to Siregar (2015: 405), multiple regression is the development of simple linear regression, which is an analysis tool that aims to determine the effect of one or more independent variables on an independent variable.

The general formulation for multiple regression is as follows: $Y=a+b_{1} X_{1}+b_{2} X_{2}+\ldots+b_{n} X_{n}+$ e. Information: $\mathrm{Y}=$ Decision to visist, $\mathrm{X} 1=$ Attractiveness, $\mathrm{X} 2=$ Word Of Mouth, $\mathrm{a}=$ constant $\mathrm{b}=$ regression coefficient of the independent variable, $\mathrm{e}=$ Residual / error. In addition to predicting the value of the Dependent Variable ( $\mathrm{Y}$ ) function, the regression equation can also be used to determine the direction and magnitude of the influence of the Independent Variable (X) on the Dependent Variable (Y).

\section{RESULTS AND DISCUSSION}

Research respondents are tourists who have visited Watu Ulo Beach in the Jember Regency, where the number of respondents was determined as many as 60 people. The following are the demographic statistics of the respondents, which included gender, age, education, occupation, and frequency of visits.

Table 1. Descriptive Statistics of Respondents

\begin{tabular}{|c|c|c|c|}
\hline & Criteria & Frequency (people) & Percentage (\%) \\
\hline \multirow{6}{*}{ Ages } & $17 \mathrm{~s} / \mathrm{d} 20$ years & 7 & 11,7 \\
\hline & $21 \mathrm{~s} / \mathrm{d} 30$ years & 24 & 40,0 \\
\hline & $31 \mathrm{~s} / \mathrm{d} 40$ years & 14 & 23,3 \\
\hline & $41 \mathrm{~s} / \mathrm{d} 50$ years & 11 & 18,3 \\
\hline & $>50$ years & 4 & 6,7 \\
\hline & Jumlah & 60 & 100,0 \\
\hline \multirow{3}{*}{ Gender } & Male & 23 & 38,3 \\
\hline & Female & 37 & 61,7 \\
\hline & Amount & 60 & 100,0 \\
\hline \multirow{8}{*}{ Education } & SD & 3 & 5,0 \\
\hline & SMP & 9 & 15,0 \\
\hline & SLTA & 26 & 43,3 \\
\hline & Diploma & 8 & 13,3 \\
\hline & S1 & 10 & 16,7 \\
\hline & S2 & 4 & 6,7 \\
\hline & S3 & - & - \\
\hline & Amount & 60 & 100,0 \\
\hline \multirow{3}{*}{ Profession } & Government & 9 & 15,0 \\
\hline & employees & 12 & 20,0 \\
\hline & Private employees & 14 & 23,3 \\
\hline
\end{tabular}




\begin{tabular}{llrr}
\hline Entrepreneur & 18 & 30,0 \\
Student / Student & 7 & 11,7 \\
Others & & 100,0 \\
\hline Amount & 60 & \\
\hline
\end{tabular}

Source: Processed data results, 2020

Based on these results, it can be stated that the majority of respondents in this study were tourists who had visited Watu Ulo Beach in Jember Regency with female gender, aged between 21-30 years, high school education background, and work background as students.

Validity means the extent to which the accuracy and accuracy of a measuring instrument (in this case, the questionnaire) perform its measurement function. Validity testing in this study was conducted with Pearson Validity correlation with product moment techniques. The validity test results can be seen in the following table:

Table 2. Recapitulation of Validity Test Results

\begin{tabular}{lcccc}
\hline Variable & Indicator & r count & Sig. & Information \\
\hline \multirow{3}{*}{ Attraction } & $\mathrm{X}_{1.1}$ & 0,763 & 0,000 & Valid \\
& $\mathrm{X}_{1.2}$ & 0,688 & 0,000 & Valid \\
& $\mathrm{X}_{1.3}$ & 0,755 & 0,000 & Valid \\
\hline \multirow{3}{*}{ Word of Mouth } & $\mathrm{X}_{2.1}$ & 0,731 & 0,000 & Valid \\
& $\mathrm{X}_{2.2}$ & 0,802 & 0,000 & Valid \\
& $\mathrm{X}_{2.3}$ & 0,774 & 0,000 & Valid \\
\multirow{3}{*}{ Decision to visit } & $\mathrm{Y}_{1}$ & 0,785 & 0,000 & Valid \\
& $\mathrm{Y}_{2}$ & 0,771 & 0,000 & Valid \\
& $\mathrm{Y}_{3}$ & 0,683 & 0,000 & Valid \\
& $\mathrm{Y}_{4}$ & 0,751 & 0,000 & Valid \\
& $\mathrm{Y}_{5}$ & 0,648 & 0,000 & Valid \\
\hline
\end{tabular}

Source: Processed data results, 2020

Based on Table 2, it can be seen that each indicator used in both the independent variable (attractiveness and word of mouth and the dependent variable (visitation decision) has a significance value of less than 0.05 , which means the indicators used in This research variable is feasible or valid to be used as a data collector.

This test is carried out to show the extent to which a measurement result is relatively consistent. A good question is a question that is clearly easy to understand and has the same interpretation even though it is submitted to different respondents and at different times. The reliability test results are as follows:

Table 3. Reliability Test Results

\begin{tabular}{|c|c|c|}
\hline Variable & $\alpha$ & Information \\
\hline Attraction & 0,569 & \multirow{3}{*}{$\begin{array}{l}\text { Reliable } \\
\alpha>0,50\end{array}$} \\
\hline Word of mouth & 0,624 & \\
\hline Decision To Visit & 0,764 & \\
\hline
\end{tabular}

Source: Processed data results, 2020

Based on Table 3, it can be stated that all variables used in this study are reliable because they have a Cronbach Alpha $(\alpha)$ value greater than 0.50. As required by Ghozali (2006) that a construct is said to be reliable if the Cronbach Alpha value is more than 0.50

The normality test aims to test whether, in the regression model, the dependent and independent variables both have normal distributions or not. Visible points spread around the diagonal line, and 
the distribution follows the direction of the diagonal line. Then the regression model is feasible because it meets the normality assumption. This test is carried out to determine whether, in a regression model, there is a variance invariance from one observation to another. The procedure is carried out by detecting the presence or absence of certain patterns in the scatter plot. The results of the analysis, do not form a certain clear pattern, and spread both above and below the number 0 on the Y-axis. This means there is no heteroscedasticity in the regression model. Multicollinearity means intercorrelation between independent variables, which indicates more than one significant linear relationship. If the correlation coefficient of the relevant variable is located outside the limits of acceptance (critical value), the correlation coefficient is significant, and multicollinearity occurs. If the correlation coefficient lies within the limits of acceptance, the correlation coefficient is not significant and does not occur multicollinearity. Based on the results of the Collinearity Statistics analysis, it is known that multicollinearity does not occur in the model, where the VIF value of each variable is less than 10 .

Multiple linear regression testing is useful to determine the level of influence of independent variables (attractiveness and word of mouth) on the dependent variable (visiting decision). Based on testing with the help of the SPSS for Windows 17.0 program. Based on these results we can get the multiple regression equation as follows: $\mathrm{Y}=1,675+0,649 \mathrm{X}_{1}+0,740 \mathrm{X}_{2}$. The results of t-test calculations using the SPSS for Windows program can be seen in Table 5. Based on the table, it can be seen the effect of each independent variable on the dependent variable as follows: a. Effect of attractiveness variable (X1) on visiting decisions (Y). Based on Table 5, it can be seen that the significance of the attractiveness variable $<\alpha$ is $0,000<0.05$. Because the probability level is smaller than $5 \%$, then $\mathrm{H} 0$ is rejected, meaning the attractiveness variable (X1) partially has a significant influence on the decision to visit Watu Ulo Beach, Jember Regency (Y). Thus, the hypothesis which states that there is an influence of attraction towards the decision to visit Watu Ulo Beach in Jember Regency is proven to be correct or accepted. b. Effect of word of mouth variable (X2) on visiting decisions (Y). Based on Table 5, it can be seen that the significance of the word of mouth variable $<\alpha$ is $0,000<0.05$. Because the probability level is less than $5 \%$, then $\mathrm{H} 0$ is rejected, meaning that partially the word of mouth variable (X2) has a significant influence on the decision to visit Watu Ulo Beach, Jember Regency (Y). Thus, the hypothesis which states that there is an influence of word of mouth on the decision to visit Watu Ulo Beach in Jember Regency is proven correct, or Ha2 is accepted.

This test aims to determine the effect of attractiveness variables and word of the mouth simultaneously on visiting decisions. This research was conducted using a significant level of 0.05 . Together the attractiveness and word of mouth variables will prove to significantly influence the visiting decision if the probability is $\leq 0.05$. Conversely, if the probability $>0.05$, then the variable attractiveness and word of mouth do not significantly influence the visiting decision. The significance value of the $\mathrm{F}$ test significance is less than $0.05(0,000<0.05)$, then the attractiveness and word of mouth variables simultaneously have a significant effect on visiting decisions. In this case, H0 is rejected. So the hypothesis which states that there is a simultaneous influence of attractiveness and word of mouth on the decision to visit Watu Ulo Beach in Jember Regency is proven true, or Ha3 is accepted. The coefficient of multiple determination (R2) is intended to determine the amount of contribution of the independent variable to the dependent variable. The coefficient of determination lies between 0 and 1 . The fit of the model will be even better when approaching one. Based on the results of the analysis that can be seen in Table 4, the results of the multiple determination coefficient (R2) of 0.558 , this means that $55.8 \%$ of the visiting decision changes are influenced by attractiveness and word of mouth variables while the remaining $44.2 \%$ is caused by other factors promotion, service quality, the image of tourist attraction, etc. that are not included in the regression equation created.

The regression test results showed that the attractiveness variable had a positive and significant effect on visiting decisions. This means that the attraction factor measured through Watu Ulo Beach has a beautiful panoramic view of the sea, Watu Ulo Beach has a uniqueness or distinctive 
attraction that is different from other beaches, and Watu Ulo Beach has sufficiently maintained cleanliness is a factor that determines the decision to visit Watu Ulo Beach, Jember Regency. The results of this study support research conducted by Setiyorini et al. (2018), which states that attractiveness significantly influences visiting decisions.

A tourist attraction is anything that has an attraction, uniqueness, and high value, which is a destination for traveling so that tourists are interested in visiting it. Tourism activities, there is a movement of people from their homes to tourist destinations or tourist destinations, is a geographical area within one or more administrative regions in which there are tourist attractions, public facilities, tourism facilities, accessibility, and community which are interrelated and complete the realization of tourism. The tourist attraction factor is one of the elements that shape and determine an area to be a tourism destination. Each tourism destination has a different attraction according to the ability or potential possessed.

One of the attractions of Watu Ulo beach is the stone protruding into the sea and shaped like a snake. This makes tourists interested in visiting the beach. This stone can be used as a photo spot for selfies, and based on data from respondents that the most dominant visitors to Watu Ulo beach are young people who are students. If we look at the current phenomenon, the purpose of teenagers doing travel activities is to capture the moment with their friends with photos (selfies). The attraction that is owned by Watu Ulo Beach is a natural (pure) attraction so that it becomes an icon of the beach. Based on these reasons, the attractiveness of Watu Ulo Beach can influence tourist visiting decisions.

Regression test results showed that the word of mouth variable had a positive and significant effect on visiting decisions. This means the word of mouth factor measured by tourists has the willingness to talk about positive things about the attractiveness of Watu Ulo Beach, tourists will recommend Watu Ulo Beach to others, and tourists give encouragement to friends or relatives to choose Watu Beach Ulo as a recreational destination is a factor that determines the decision to visit Watu Ulo Beach, Jember Regency. The results of this study support research conducted by Ruhamak and Sya'idah (2018), which states that word of mouth significantly influences visiting decisions.

Kotler \& Keller (2007: 204) suggested that word of mouth Communication (WOM) is a communication process in the form of providing recommendations both individually and in groups of a product or service that aims to provide personal information. Word of mouth communication is one of the communication channels that is often used by companies that produce both goods and services because word of mouth communication is considered very effective in expediting the marketing process and able to provide benefits to the company. According to Hasan (2010: 32), word of mouth is the act of consumers providing information to other consumers (interpersonal) non-commercial, both brands, products, and services. Rangkuti (2009: 77) defines WOM as a marketing effort that triggers customers to discuss, promote, recommend, and sell a product, service, or brand to other customers. Mowen and Minor (2002: 180) say that word of mouth communication refers to the exchange of comments, thoughts, or ideas between two or more consumers, none of which are marketing sources. WOM is defined as a form of communication about goods and services between people independent people, are not part of the company providing the product, which occurs through a medium that is also believed to be independent.

Word of mouth can influence the decision to visit Watu Ulo Beach because, based on information from respondents, one of the factors that make them visit the beach is based on recommendations and information from others, so tourists are interested in visiting Watu Ulo Beach.

The results showed that the attractiveness and word of the mouth simultaneously influenced the decision to visit Watu Ulo Beach. Based on these results together, the appeal and word of the mouth simultaneously influence the decision to visit Watu Ulo Beach. Based on the simultaneous test results obtained by the coefficient of multiple determination (R2) of 0.558 , this means that 
$55.8 \%$ change in visiting decisions is influenced by the attractiveness and word of mouth variables while the remaining $44.2 \%$ is caused by other factors promotion, service quality, the image of tourist attraction, and others which are not included in the regression equation created. The results of this study support research conducted by Setiyorini et al. (2018), which shows that attractiveness and word of the mouth simultaneously influence the decision to visit Watu Ulo Beach.

\section{CONCLUSION}

Based on the results of the analysis, the following conclusions can be drawn: 1. There is an influence of attraction towards the decision to visit Watu Ulo Beach in the Jember Regency. 2. There is an influence of word of mouth on the decision to visit Watu Ulo Beach in Jember Regency. 3. There is a simultaneous influence of attractiveness and word of mouth on the decision to visit Watu Ulo Beach in the Jember Regency. From the results of this study, researchers can provide advice, including: 1 . The results of the research prove that attractiveness and word of mouth have a significant effect on the decision to visit Watu Ulo Beach, Jember Regency. Therefore companies should, in this case, Watu Ulo Beach Jember Regency, always pay attention to things specifically related to attractiveness and word of mouth, such as maintaining the natural attraction of Watu Ulo Beach by maintaining the cleanliness of the beach so that it can provide a good image in the minds of tourists so that tourists will recommend the beach to others and can influence the decision to visit. 2. The results of this study are only able to explain the decision of visiting by $55.8 \%$, so there are still other factors outside the model studied that are able to explain the decision of visiting. Therefore it is recommended for further research to add other variables such as promotion, service quality, the image of tourist attraction, and others. So that it can obtain better and useful findings for the development of knowledge, especially marketing management.

\section{REFERENCE}

Al-Ababneh, M. (2013). Service Quality and its Impact on Tourist Satisfaction. Interdisciplinary Journal of Contemporary Research in Business, Vol 4, No. 12, 164-177.

Hasan, A. (2010). Marketing, Edisi Baru. Yogyakarta : Media Pressindo.

Kotler, P. (2007). Manajemen Pemasaran, jilid 1. Edisi Bahasa Indonesia. Jakarta : PT Indeks.

Medlik, S. \& Middleton, V.T.C. (1973). Product formulation in tourism. Tourism and Marketing, 13.

Middleton, V. and Clarke, J. (2001). Marketing in Travel and Tourism, $3^{\text {rd }}$ edition, Elsevier.

Mowen, J. C., \& Minor, M. (2002). Perilaku konsumen. Jakarta: Erlangga, 90.

Rangkuti, F. (2009). Mengukur Efektivitas Program Promosi \& Analisis Kasus Menggunakan SPSS. PT Gramedia Pustaka Utama.

Sangadji, E. M., \& Sopiah, S. (2013). Perilaku Konsumen. Yogyakarta: Penerbit Andi.

Sekaran, Uma. (2006). Metode Penelitian untuk Bisnis. Jakarta : Salemba Empat.

Setiyorini, Anis dkk. (2020). Pengaruh Promosi Melalui Media Sosial, Word Of Mouth, Dan Daya Tarik Wista Terhadap Keputusan Berkunjung Wisatawan. Jurnal: Ekonomi, Manajemen Dan Akuntansi. Volume 2 No. 1 April 2018, Halaman 12-17.

Sugiyono. (2009). Metode Penelitian Bisnis. CV. Alfabeta. Bandung.

https://www.indonesia-investments.com/id/bisnis/industri-sektor/pariwisata/item6051. Online. Di akses tanggal 10 februari 2020. 